\title{
ISLAM, POLITICS AND IDENTITY IN WEST SUMATRA
}

\author{
Delmus Puneri Salim \\ STAIN Manado - Indonesia
}

\begin{abstract}
Since Indonesia has undergone a decentralisation phase, its regions have searched for their local identities. In West Sumatra, for instance, Islam is dominant. Consequently, there has been a constant attempt to infuse Islamic values into social, political and economic aspects. The paper seeks to contextualise the key phases in the history of West Sumatra in the broader history of the archipelago and the Malay world, and to show how key events in West Sumatra and at the national level set the parameters for later debates about Islam and identity in the region. The paper argues that now, as in the past, the relationship between Islam, a global religion, and Minangkabau culture was, and is, simultaneously contested. It is also found that Islam as an ideology was subordinated after Independence days, and again under the New Order. The strong association between Islam and regional identity only solidified in the post-Suharto. Now, regional governments has been utilising claims that local customs are based on Islam and Islam is based on the Qur'an.
\end{abstract}

Keywords: Sufism, orthodoxy, Minangkabau, Malay world.

\section{Introduction}

Before the arrival of Islam, The Minangkabau people believed a South Indian version of Hindu-Buddhism brought to the region by Indian merchants in the third and fourth centuries. ${ }^{1}$ They are also a matrilineal society in which ancestral property such as land and houses arepassed down from mothers to daughters. Kinship is also based around the female line.

${ }^{1}$ I. Manan, "A Short History of Minangkabau," in A. Summerfield and J. Summerfield (eds), Walk in Splendor: Ceremonial Dress and the Minangkabau (Los Angeles: UCLA Fowler Museum of Cultural History, 1999), p. 50. 
In the seventh century, Sumatra was very much part of the Malay world (Alam Melayu). That world was based around the powerful and prosperous Hindu-Buddhist kingdoms of Srivijaya, based in Bukit Seguntang in Palembang, and Melayu, which was associated with the Batang Hari River in Jambi. ${ }^{2}$ In the eleventh century, after the collapse of Srivijaya, and in a period when international trade between India and China through the Straits of Malacca came to be dominated by the Cholas of India, the term Melayu referred to interior areas in Jambi. ${ }^{3}$ In the fourteenth century, Melayu appeared in Javanese literature, where it referred to an area that extended to other territories such as Lampung, Pattani in modern Thailand, Kelantan in Malaysia and the Minangkabau region of West Sumatra. ${ }^{4}$ In that same century, Malacca, a region made prosperous by its position at the centre of key trading routes, emerged as the new centre of the Malay world. Because of the establishment of the kingdom of Malacca, the name Melayu and its defining characteristics such as dress, language and religion became associated with Malacca Malays. ${ }^{5}$ When Malacca became a powerful Muslim state in the same century, Islam came to be identified with Malay culture. This connection then began the association of Islam with the Malay people. ${ }^{6}$ While a Hindu-Buddhist Minangkabau kingdom was established in 1347 by Adityawarman, a prince from the post-Srivijaya kingdom of Dharmasyraya who was raised in the Javanese kingdom of Majapahit, ${ }^{7}$ those living in the coastal areas of West Sumatra identified themselves as Malays rather than Minangkabau, as a result of the influence of the Malaccan Malays. ${ }^{8}$

2 L.Y. Andaya, “Aceh's Contribution to Standards of Malayness," Archipel, 61 no. 1 (2001), p. 31.

${ }^{3}$ Ibid.

4 A. Reid, "Understanding Melayu (Malay) as a Source of Diverse Modern Identities," Journal of Southeast Asian Studies, 32 (2001): pp. 295-313.

5 Andaya, “Aceh's Contribution to Standards of Malayness," p. 33

${ }^{6}$ E. Utrecht, "The Muslim Merchant Class in the Indonesian Social and Political Struggles," Social Compass, 31 no. 1 (1984), p. 31.

${ }^{7}$ F. Colombijn, Paco-paco (kota) Padang: Sejarah Sebuah Kota di Indonesia pada abad ke 20 dan Penggunaan Ruang Kota (Yogyakarta: Penerbit Ombak, 2006), p. 55.

8 J. Drakard, A. Malay Frontier: Unity and Duality in A Sumatran Kingdom (New York: Southeast Asia Program, Cornell University, 1990), p. 11. 
Scholars have proposed a number of theories to explain the conversion of the Malay world to Islam. Al-Attas argues that Islam was introduced directly by Arabs to Malay Sumatra in the seventh century, citing a Chinese report of the existence of an Arab settlement in East Sumatra in 674, the earliest known record of probable Muslim settlement in Malay Sumatra. Others argue that Islam came to the Malay world from India in the twelfth century, citing the existence of international maritime trade routes, the commonality of schools of jurisprudence and the similarity of gravestones and literary styles and themes between India and the Malay world as evidence for this theory. Others say that Islam came from India to Sumatra at the end of the thirteenth century through the kingdoms of Pasai and Perlak. ${ }^{9}$ What is clear is that in the fourteenth century, the laws of Malacca (Undangundang Melaka) used the term 'Kanun' (Arabic qanun) meaning administrative law, as used in the Ottoman Empire, and the Pasai chronicle of Aceh also frequently invokes both the terms 'adat' (from the Arabic 'ádab), meaning customs, and 'Kanun'. ${ }^{10}$

Importantly also, merchant Arabs from the Hadramaut (now Yemen and Oman), who had visited and settled in Malay Sumatra before the seventeenth century, settled in the Straits of Malacca and what is now called South Sumatra, from the late seventeenth century. ${ }^{11}$ Many reformist Muslims in the Malay world, such as Nuruddin AlRaniri and Sayyid Abd Al-Samad Palimbani, were of Hadramaut descent. ${ }^{12}$ This contact continued into the early twentieth century, when Ahmad Surkati taught Islam at various schools in Batavia (Jakarta). By the early twentieth century, there were more than twenty thousand Hadramauti Arabs in the archipelago. ${ }^{13}$

\footnotetext{
9 Andaya, “Aceh's Contribution to Standards of Malayness," p. 36.

10 A.C. Milner, "Islam and Malay Kingship," Journal of Royal Asiatic Society, 113 (1981), p. 47.

11 W. Roff. The Origins of Malay Nationalism (New Haven: Yale University Press, 1964), p. 81.

12 Azyumardi Azra, Jaringan Global dan Lokal: Islam Nusantara (Bandung: Mizan, 2002), p. 139.

13 A. Reid, An Indonesian Frontier: Acehnese and Other Histories of Sumatra (Singapore: Singapore University Press, 2005), p. 230.
} 


\section{The Arrival of Sufism}

Sufism, which came to Malay Sumatra via the trading routes between various parts of Asia and the Middle East, was an important element in the introduction of Islam to the Malay world. Sufi Islam emphasised the belief that it is possible to have direct experience of God or direct communication with God under the guidance of charismatic leaders. ${ }^{14}$ The mystical expression of the Islamic faith has both an intellectual dimension, consisting of Sufi teaching, and an organisational dimension called tariqah (tarekat in Indonesian), or brotherhood. ${ }^{15}$

Sufi traders used Islam as a means of establishing cooperation with local chiefs and the merchant class. Because of the dominance of trade in the region, the centres of religious power were at the same time centres of economic power. ${ }^{16}$ As Utrecht points out, Islam took hold fastest among the trader class. ${ }^{17}$ Wealthy merchants had the means to fund the education of their children and to fulfil the religious obligation to undertake the pilgrimage to Mecca, which consequently brought them into closer contact with Islam. ${ }^{18}$ Sufism was, however, subsequently transmitted through other channels, as Sufi teachers married the daughters of Malay Indonesian nobility, which mean that their children had royal blood and therefore were well-placed to spread Islam. ${ }^{19}$

${ }^{14}$ J.S. Trimingham, The Sufi Orders in Islam (Oxford: Oxford University Press, 1998), p. 1

${ }^{15}$ J. Voll, "Foreword." in Trimingham, The Sufi Orders, vii; Howell argues that the term Sufi has many different meanings. It can be associated with devotional practices and religious concepts that are quite separate from Sufism's common association with mysticism. See J.D. Howell, "Sufism and the Indonesian Islamic Revival," The Journal of Asian Studies, 60 no. 3 (2001): pp. 701-729.

${ }^{16}$ Kahane, among others, has pointed out that economic interests, not purely religious motives, enhanced the spread of Islam into the Malay archipelago. See, R. Kahane, "Religious Diffusion and Modernisation: A Preliminary Reflection on The Spread of Islam in Indonesia and Its Impact on Social Change," European Journal of Sociology, 21 no. 1 (1980): pp. 116-137.

${ }_{17}$ Utrecht, “The Muslim Merchant Class,” p. 33.

18 H.M. Federspiel, Persatuan Islam, Islamic Reform in Twentieth Century Indonesia (New York: Ithaca Cornell University, 1970), p. 7.

${ }^{19}$ H. Johns, "Sufism as A Category in Indonesian Literature and History," Journal of Southeast Asian History, 2, no. 2 (1961), p. 17. 
The nature of Sufism played an important role in the acceptance of Islam in Malay Sumatra. Johns argues that the Sufis who preached Islam in the region 'were prepared to preserve continuity with the past and to use the terms and elements of pre-Islamic culture in an Islamic context'. ${ }^{20}$ As Sufi Islam did not challenge local animist beliefs, it could penetrate the Malay world in a peaceful way. At the same time, however, some scholars argue that Sufi Islam created a new identity in the Malay world, ${ }^{21}$ serving as 'a liberation creed' against the feudalism of the Hindu society and caste system imported from India and institutionalised under the Hindu kingdoms. ${ }^{22}$ Islam also provided local rulers with a consensual basis upon which to engage with Muslim merchants in coastal towns. ${ }^{23}$ According to Woodward, ${ }^{24}$ the majority of the population, notably the lower classes in urban centres, were eager to liberate themselves from the caste system, quickly embracing the idea of equality before God and Sufism's emphasis on merit instead of inherited status. However, as other scholars have pointed out, the ruling classes did not only convert to Islam themselves, but also encouraged the general populace to do so as well. ${ }^{25}$

Sufi Muslim merchants from Gujarat and Persia began visiting West Sumatra in the thirteenth century, establishing trade links through the gold industry. Gold traders from both the west and east coasts of Sumatra carried Sufi Islam with them to the Minangkabau highlands and the centres of the gold trade became the first to be converted to Islam. ${ }^{26}$ Three centuries later, one of the Minangkabau kings converted to Islam. ${ }^{27}$ Conversion took place on a large scale in the seventeenth century, when a Sufi centre was established in Ulakan

\footnotetext{
${ }^{20}$ Ibid., p. 15.

${ }^{21}$ Utrecht, "The Muslim Merchant Class,"; M. Woodward, Islam in Java: Normative Piety and Mysticism in the Sultanate of Yogyakarta (Tucson: University of Arizona Press, 1989).

22 Utrecht, "The Muslim Merchant Class," p. 30.

${ }^{23}$ Kahane, "Religious Diffusion and Modernisation," p. 130.

${ }^{24}$ Woodward, Islam in Java: Normative Piety.

${ }^{25}$ Johns, "Sufism as A Category".

${ }^{26}$ C. Dobbin, Islamic Revivalism in a Changing Peasant Economy: Central Sumatra, 1784-184 (London: Curzon Press, 1983), p. 119.

${ }^{27}$ J. Hadler, Muslims and Matriarchs (London: Cornell University Press, 2008b), p. 977.
} 
in the district of present-day Padang Pariaman. ${ }^{28}$ Syaikh Burhanuddin, known as the Tuanku (religious leader) of Ulakan, was the first Sufi teacher of the tarekat organisation, Syattariyah, in Ulakan. ${ }^{29}$

\section{The Influence of Orthodoxy}

The hold of Sufism in West Sumatra was not to go unchallenged. Changes in the wider Islamic world and their continuing impact on Malay Muslims gradually affected the form of Islam in the region. The modern reform movement only became influential in the nineteenth century, but orthodox Islam began infiltrating Sumatra as early as the seventeenth century. The first orthodox Muslim preacher in Malay Sumatra was Nuruddin al-Raniri, from Randir in Gujarat, who had studied Islam in Mecca before travelling to Aceh in 1637.30 Raniri favoured the orthodoxy that he had learned in the Middle East over the Sufi mysticism that had its roots in India, and he set about spreading the teachings of a more shari'a-oriented Islam. ${ }^{31}$

According to van Dijck, ${ }^{32}$ the introduction of orthodox Islam into the Malay world marked the beginning of a new chapter in the relationship between Islam and the state, in which Islam became a considerable source of social tension, ranging from dissatisfaction with indigenous symbols, rebellion against local rulers, to all-out war. The most important of these conflicts in West Sumatra was the Paderi war, which took place between 1803 and 1837. It was initiated by West Sumatran pilgrims returning from Mecca, who sought to implement

${ }^{28} \mathrm{~J}$. Hadler, "A Historiography of Violence and the Secular State in Indonesia: Tuanku Imam Bondjol and the Uses of History," The Journal of Asian Studies, 67 no. 3 (2008a), p. 977.

29 Taufik Abdullah, "Adat and Islam: An Examination of Conflict in Minangkabau," Indonesia 2, no. 1 (1966): pp. 1-24. There is some disagreement on this. According alAttas, the Acehnese Syaikh Abdullah Arif, Sheikh Burhanuddin's teacher, introduced Islam into Padang Pariaman in West Sumatra in the seventeenth century. See, S.M.N. Al-Attas, Preliminary Statement on a General Theory of the Islamization of The Malay-Indonesian Archipelago (Kuala Lumpur: Dewan Bahasa dan Pustaka. 1969).

30 Azyumardi Azra, The Origins of Islamic Reformism in Southeast Asia: Networks of MalayIndonesian and Middle Eastern Ulama in the Seventeenth and Eighteenth Century (Honolulu: University of Hawaii Press, 2004).

${ }^{31}$ Ibid., p. 63

32 C. van Dijck, "Islam and Socio-Political Conflicts in Indonesian History," Social Compass, 31, no. 1 (1984), p. 8. 
the principles of Wahhabism they had encountered in Saudi Arabia over the way Islam was practised their homeland. The term itself was derived from Pedir or Pidie, the part of Aceh where Malays set out on and returned from the pilgrimage. ${ }^{33}$

According to Dobbin, ${ }^{34}$ the Paderi war exploited changing economic and social relations among the Minangkabau. The collapse of the existing cash economy, which had been based on gold mining, led to the emergence of a new system based on the cultivation of coffee, which transformed economic and political relationships between and within villages. The wealthy were thrown into turmoil by the collapse of the gold industry at precisely the same time that it became possible for those at the bottom of the economic ladder to cultivate coffee in the hills on common village lands without the need for large investments. This gave rise to a group of 'new rich' farmers eager to challenge the economic order. ${ }^{35}$ Before the Paderi war, an emerging leader of this group, Tuanku Nan Tuo, had taken steps to secure trading routes by promoting Islamic regulations and confronting those responsible for robberies and other forms of misconduct. ${ }^{36}$ According to Dobbin, ${ }^{37}$ the introduction of Islamic regulations also made it possible for leaders such as Tuanku Nan Tuo to claim the land necessary for coffee cultivation from traditional landholders, thus further cementing the new economic order.

The Paderi movement emerged in these newly rich coffee villages. It sought to challenge the entrenched positions of wealthy traditional leaders, aiming to replace what its followers perceived to be a corrupt traditional order with the laws of Islam. ${ }^{38}$ The movement's most prominent leader was Peto Syarif, who became better known as Tuanku Imam Bonjol. Establishing a fortress in Bonjol, the Paderi movement flourished for thirty-five years, before the Dutch, acting in support of the traditional order, finally took full control of the Minangkabau heartlands in 1837. The Paderi leaders were subsequently

\footnotetext{
33 Ibid., p. 10.

34 Dobbin, Islamic Revivalism in a Changing Peasant Economy.

${ }^{35}$ van Dijck, "Islam and Socio-Political Conflicts," p. 9.

36 Ibid., p. 10.

${ }^{37}$ Dobbin, Islamic Revivalism in a Changing Peasant Economy, pp. 127-8.

38 van Dijck, "Islam and Socio-Political Conflicts," p. 10.
} 
captured and exiled, ${ }^{39}$ bringing the Paderi movement to an end. However, some Paderi leaders joined the tarekat Naqsabandiyah, which later attacked the Sufi tarekat, Syatariyah. ${ }^{40}$

By attacking the authority of traditional leaders, the Paderi movement also attacked an interpretation of Islam, since customary law (adat) and Islam had influenced one another for centuries, and both had come to incorporate elements of the other. ${ }^{41}$ West Sumatra's adat leaders were also Muslims, albeit superficial and heterodox in the eyes of the Paderi movement. Indeed, the complexities of the Paderi war point to the fact that adat and Islam may be interpreted differently, and each may be used for political or economic gain. ${ }^{42}$

\section{Islamic Politics under the Dutch}

The Dutch, who had an interest in gaining control over the coffee trade, sided with traditional adat leaders against the Paderi movement. ${ }^{43}$ They continued to favour the adat leaders, promising them taxation concessions in the 1833 Long Declaration (Plakat Panjang), which abolished a cultivation system in favour of a direct tax. ${ }^{44}$ This enabled the Paderi movement to identify adat leaders as friends of the enemy. Indeed, the term 'Adat Basandi Syarak' (local customs are based on Syari'a), among the Minangkabau of West Sumatra, was coined by Tuanku Imam Bonjol during the Paderi war specifically in response to the Dutch positioning of adat as a superior source of authority over Islam. ${ }^{45}$

\footnotetext{
${ }^{39}$ Dobbin, Islamic Revivalism in a Changing Peasant Economy, pp. 193-206.

40 TaufikAbdullah, "Modernisation in the Minangkabau World: West Sumatra in the Early Decades of the Twentieth Century," in C. Holt (ed.), Culture and Politics in Indonesia (Ithaca: Cornell University Press, 1972), p.203.

${ }^{41}$ van Dijck, "Islam and Socio-Political Conflicts," p. 11.

42 R. Biezeveld, "The Many Roles of Adat in West Sumatra," in J.S. Davidsonand D. Henley, The Revival of Tradition in Indonesian Politics: the Deployment of Adat from Colonialism to Indigenism (London, New York: Routledge, 2007).

43 Ibid., p. 208.

44 A. Kahin, Rebellion to Integration: West Sumatra and the Indonesian Polity (Amsterdam: Amsterdam University Press, 1999), p. 25.

45 Hadler, “A Historiography of Violence," p. 986. 'Adat basandi Syarak, Syarak basandi Adat' was widely accepted as a form of compromise between Islamic and adat leaders by 1837. See Hadler, Muslims and Matriarchs, p. 29.
} 
In 1847, the Dutch appointed adat leaders in West Sumatra as colonial agents charged with collecting the coffee harvest through forced cultivation, in order to improve the collection and delivery of this crop. At that time, the new position of 'traditional leader responsible for forced labour' (panghulu suku rodi) was created to implement the government's coffee policies in many nagari, with the salaries attached to the positions being a percentage of the coffee production of their areas. ${ }^{46}$ When the Dutch introduced the Ethical Policy at the end of the nineteenth century, local Muslims interpreted it as not only being linked to the Dutch support for adat, but also as part of the effort to undermine Islam and strengthen the position of Christian missionaries. ${ }^{47}$

In 1914, the Nagari Ordinance was passed with the aim of reestablishing West Sumatra's autonomous village communities and recognising the right of adat leaders to hold authority in the nagari. ${ }^{48}$ The Dutch also attempted to codify adat in 1929, using information gathered from native customary law tribunals, the opinions of chiefs and elders who were consulted by van Vollenhoven and other adat scholars. ${ }^{49}$ The key issues at stake were those of marriage, divorce, and inheritance, issues over which there was a real competition between adat and Islamic law.

In the early twentieth century, attacks on traditionalist Islam in West Sumatra were coming from the proponents of both secular modernity and modernist Islam. In 1906, Datuk Sutan Maharaja established a movement that promoted education for women on the basis of their status in Minangkabau culture. In order to improve their position, he established twelve schools for women and a feminist newspaper, Sunting Melayu (Malay Ornament), which was edited by his daughter, Ratna Djuita and later by Rohana Kudus, the 'Kartini of

\footnotetext{
46 Kahin, Rebellion to Integration, p. 26.

${ }^{47}$ H.J. Benda, The Crescent and the Rising Sun: Indonesian Islam under the Japanese Occupation (The Hague: W. van Hoeve, 1958), p. 339.

${ }^{48}$ Kahin, Rebellion to Integration, p. 26.

49 M.A. Jaspan, "In Quest of New Law: The Perplexity of Legal Syncretism in Indonesia," Comparative Studies in Society and History, 7 no. 3 (1965), p. 252.
} 
West Sumatra'..$^{50}$ In 1910, he went on to establish the Minangkabau Union (Minangkabausche Bond) to unite all Minangkabau people living in the darek and the rantau including Aceh and Negeri Sembilan. At the same time, reformists Muslim led by those who had been students of Syaikh Achmad Khatib in Mecca, such as Djamil Djambek in Bukittinggi, Haji Abdullah Ahmad in Padang, Haji Rasul in Padang Panjang, and Taib Umar in Batu Sangkar, among others, not only challenged the adat-oriented interpretation of progress favoured by Datuk Sutan Maharaja, but also attacked the heterodoxy of the Sufi orders and the Minangkabau matrilineal inheritance system, arguing that the former two ideas were heretical and the later was an infringement of Sharia. ${ }^{51}$ Reformist Muslim ideas had spread in Indonesia after the opening of Suez Canal in the nineteenth century, which saw an increasing number of pilgrims travelling from the archipelago to Mecca and Egypt. As Laffan has demonstrated, these connections were crucial to the Indonesian nationalist movement because they provided an alternative model to Europe for modernising intellectuals. ${ }^{52}$

Influenced by the Young Turks movement in the Ottoman Empire, a group of reformist Minangkabau Muslims called the Kaum Muda (Group of the Young), set themselves up in opposition to the Kaum Tua (Group of the Elders), a term they used to refer to the Sufi orders. ${ }^{53}$ As in other parts of the Malay world, the reformists attacked Sufi heterodoxy, urging a return to the Qur'an and the Hadith. They also denounced Islamic practices which they saw as heterodox, for example the way in which the Prophet's birthday was celebrated. In the case of the matrilineal system, however, the Kaum Muda compromised

50 Taufik Abdullah, Schools and Politics: the Kaum Muda Movement in West Sumatra (19271933) (Ithaca, N.Y: Cornell Modern Indonesia Project, Cornell University, 1971), p. 12.

51 Taufik Abdullah, "Islam, History, and Social Change in Minangkabau', in L.L. Thomas and F.V. Benda-Beckmann, Change and Continuity in Minangkabau: Local, regional and Historical Perspectives on West Sumatra (Athens, Ohio: Ohio University Centre for International Studies, 1985), p. 141.

52 M. Laffan, Islamic Nationhood and Colonial Indonesia: The Umma Below the Winds (London and New York: RoutledgeCurzon, 2003); See also, Azra, The Origins of Islamic Reformism in Southeast Asia.

53 Abdullah, Schools and Politics, p. 16. 
by suggesting that inheritance be divided into two categories, 'high inheritance' (pusaka tinggi) or 'ancestral inheritance' (barto pusako) and 'low inheritance' (pusaka rendab)or 'individual inheritance' (barta pencaharian). The first category would continue to be distributed according to the matrilineal line, while the second category was to be transferred in accordance with Islamic inheritance law. ${ }^{54}$ The division in the inheritance system shows how firmly Islam had become part of Minangkabau identity.

\section{Nationalism of West Sumatran Muslim}

In the early twentieth century, an anti-Dutch rebellion broke out in Minangkabau after the 1908 introduction of direct taxation by the Dutch, a policy that disregarded the promises made to adat leaders in the Long Declaration. Uprisings ensued in many parts of West Sumatra, led by both Islamic and adat leaders. Cooperation between the Islamic and adat leaders marked the genesis of nationalism in the struggle against the Dutch in West Sumatra. 55

Meanwhile, tensions between the Kaum Muda and Kaum Tua were initially reduced with the emergence of the nationalist movement. The vehicle for reconciliation was the establishment of a branch of Sarekat Islam in Padang in 1915 by two Kaum Tua leaders, Haji Achmad, a local Muslim merchant, and Syaikh Chatib Ali, a Kaum Tua leader. A number of Kaum Muda followers joined the organisation, ${ }^{56}$ but the truce did not last long. Five months later, the Padang branch of Sarekat Islam split into two opposing groups, the White Card (Kartu Putib) faction established by the Kaum Muda and the Red Card (Kartu Merah) faction aligned with the Kaum Tua. The more left-wing Red Card faction was recognised by Sarekat Islam in Java because of its opposition to Dutch colonialism while the White Card faction had the approval of the Dutch. ${ }^{57}$

\footnotetext{
${ }^{54}$ Abdullah, "Islam, History, and Social Change," p. 143.

55 Kahin, Rebellion to Integration, p. 27.

56 Abdullah, Schools and Politics,pp. 24-6.

${ }^{57}$ Datuk Sutan Maharaja responded to the establishment of the West Sumatran Sarekat Islam by forming a Minangkabau Adat party called the Adat Association of the Minangkabau World (Sarekat Adat Alam Minangkabau, SAAM) in September 1916. Most of the party's members were local panghulu and their adat staff. Datuk Sutan Maharaja not only cooperated with the Dutch but also formulated his own
} 
Muhammadiyah also came to play an important role in the Kaum Muda movement. Muhammadiyah was introduced to West Sumatra in 1925 by Abdul Karim Amrullah, also known as Haji Rasul, a strident opponent of communism who had spent time in Java. By 1927, onefifth of the whole population of his nagari of Sungai Batang, Maninjau, around 2,440 people, had joined the organisation. ${ }^{58}$ From Maninjau, Muhammadiyah subsequently established branches in Padang Panjang in 1926, Bukittinggi in 1927, Padang and Batusangkar in 1928, where it provided a base for West Sumatrans who sought to distance themselves from the revolutionary communists who dominated the local branch of Sarekat Islam. ${ }^{59}$

\section{Islam and the Rise of Political Parties}

From the 1920s to the1940s, a range of political parties emerged in Indonesia as the level of political activism increased.the Kaum Muda established a politically-oriented socio-economic organisation, the Association of Indonesian Muslims (Persatuan Muslim Indonesia, Permi) in 1930, which became a political party in 1932.60 The Kaum Tua established the Association of Islamic Schools (Persatuan Tarbiyah Islamiyah, PTI) in the same year. ${ }^{61} \mathrm{~A}$ local branch of the PSII was established in 1930, while a local branch of the PNI was established in 1932.62 In 1932, Permi proclaimed itself as a revolutionary and non-cooperative party by refusing to hoist the Dutch flag during religious celebrations. ${ }^{63}$ In 1933, Kaum Tua, Kaum Muda,

explanations for the relationship between adat and religion, in which adat was positioned as being in line with Sufi Islam, and tasauf (a personal approach to God). His rejection of the idea that adat should be directly based on Islamic laws, as was claimed by Kaum Muda movement, led him to cooperate with the Kaum Tua. See Abdullah, "Modernisation in the Minangkabau World," p. 230 and p. 232.

58 Abdullah, Schools and Politics,p. 78.

${ }^{59}$ Ibid., p. 71, and pp. 84-90. Kahin argues that West Sumatran society at this time was plural and the categorisation of society into adat, Islamic and communist blocs is unhelpful. See Kahin, Rebellion to Integration, p. 84.

${ }^{60}$ Deliar Noer, The Modernist Muslim Movement in Indonesia 1900-1942 (Kuala Lumpur: Oxford University Press, 1973), p. 50.

${ }^{61}$ Abdullah, Schools and Politics, p. 135.

62 Ibid., p. 110 and p. 183

63 Ibid., p. 176. 
Muhammadiyah and the local branch of PSII also began to adopt a revolutionary stance. ${ }^{64}$ In response, in 1933 the Dutch imprisoned the leaders of Permi and the PSII, including Rasuna Said, Rasimah Ismail, Datuk Singo Mangkuto and Djamaluddin. ${ }^{65}$ In 1938, the colonial authorities established the Minangkabau Council (Dewan Minangkabau) in an attempt to control increasingly radical local political organisations. ${ }^{66}$

\section{Islamic Politics and the Japanese Occupation}

The arrival of the Japanese in 1942 increased enthusiasm for the cause of independence. The Japanese not only put an end to Dutch power but also promoted nationalist and anti-Western sentiments in the country. ${ }^{67}$ Japanese troops arrived in Padang in March 1942 and the local Dutch commander surrendered ten days later. ${ }^{68}$ West Sumatra was then managed by the Department of Military Administration (Gunseibu) of the $25^{\text {th }}$ Army in Singapore, one of three Japanese military commands in Indonesia; other two being the $16^{\text {th }}$ Army in Java and the Navy in the eastern islands and Kalimantan. ${ }^{69}$ A year later, the 25 th Army headquarters moved to Bukittinggi, from where it administered the whole of Sumatra. ${ }^{70}$

In West Sumatra, the Japanese established a People's Committee (Komite Rakyat) to succeed the Dutch Minangkabau Council, along with an organisation called Greater Japan Youth (Pemuda Nippon Raja) led by Chatib Sulaiman. However, after the Japanese consolidated their authority in the region in late 1942, all organisations were banned from political activities. ${ }^{71}$ After suppressing political

\footnotetext{
${ }^{64}$ Divisions between Islamic organisations also emerged. For example, Permi accused Muhammadiyah of being too close to the Dutch while Muhammadiyah accused Permi activists of not being motivated by Islam. Noer, The Modernist Muslim Movement, p. 264.

${ }^{65}$ Kahin, Rebellion to Integration, p. 56.

66 Ibid., p. 90.

${ }^{67}$ A. Vickers, A History of Modern Indonesia (Cambridge: Cambridge University Press, 2005), pp. 86-7.

${ }^{68}$ Kahin, Rebellion to Integration, p. 95.

${ }^{69}$ Vickers, A History of Modern Indonesia, p. 88.

${ }^{70}$ Kahin, Rebellion to Integration, p. 95.

${ }^{71}$ Ibid., pp. 79-80.
} 
organisations, the Japanese authorities sought to play a role both within adat and Islam. At the supra-village level, they favoured Islam, for example, by sending Islamic leaders from West Sumatra to a Malay Islamic conference in Singapore and establishing the Minangkabau Supreme Islamic Council (Majlis Islam Tinggi Minangkabau) in 1943. ${ }^{72}$ At the village level, on the other hand, local adat leaders were given power through the maintenance of the Dutch administrative apparatus. ${ }^{73}$

\section{Islamic Politics after Independence}

West Sumatra was deeply involved in national politics, and in the politics of Islam, during the Sukarno years as a consequence of the engagement of Minangkabau figures like Haji Agus Salim from the PSII, Hatta and Sjahrir in the nationalist movement, and their subsequent rise to power within the Republican ranks. The province itself was also a site of Republican activity. In an attempt to shore up support for a return to colonial status, the Dutch promoted the concept of a Minangkabau state (Negara Minangkabau) through local adat leaders, introducing a form of regional government called General Unity (Persatuan Umum), which had a military arm called the Association of Black Cats (Serikat Kucing Hitam) in 1946. This initiative, which attracted adat leaders who had been officials during the Dutch colonial period, served to increase the polarisation between these local leaders and Islamic groups. ${ }^{74}$

As part of its campaign against the Republicans, in 1947, the Dutch introduced the Special Autonomous Region of West Sumatra (Daerah Istimewa Sumatera Barat, DISBA) in Padang, as a step towards the planned establishment of the Negara Minangkabau in 1949. ${ }^{75}$ Ultimately, however, this initiative failed, and, as noted above, Bukittinggi became the seat of the Emergency Government of the

\footnotetext{
72 Oki, A. Social Change in the West Sumatran Village: 1908-1945. 1978. Available at: http://hdl.handle.net/10086/16895, accessed on 12 February 2010.

${ }^{73}$ Kahin, Rebellion to Integration, p. 106.

${ }^{74}$ Ibid., pp. $110-1$.

${ }^{75}$ Ibid., p. 152.
} 
Republic of Indonesia (Pemerintahan Darurat Republik Indonesia, PDRI) after the Dutch attack on Yogyakarta in 1948. ${ }^{76}$

Relations between the Republic and local Muslim politicians began to sour with the signing of the Linggajati Agreement in 1947. Islamic groups such as Masyumi and Muhammadiyah and religious militia such as Hizbullah, Sabilillah and Lasjmi accused the regional Republican and military leaders of continuing to maintain close ties to the Dutch and proceeded to stage an attempted coup in March 1947. Kahin ${ }^{77}$ argues that the attempted coup was prompted not only by suspicions of the regional Republican government's close relationship with the Dutch but also because Islamic political parties were not represented in the village administration and in the regional Republican government. They also resented the fact that local Islamic militias were not given arms. Islamic groups, according to Kahin, considered higher-ranking military officers to be adopting luxurious and immoral lifestyles that were inconsistent with Islamic principles. ${ }^{78}$ Attempts were made to bring Islamic militia groups under the control of the regular army after the formation of the Banteng Division in 1947. The fusion of the militias and the regular forces was not particularly successful, as some militia commanders refused to forfeit their independence and some military units remained loyal to their militia commanders and to various political parties.

The West Sumatran division of Masyumi joined a movement created by veterans of the Banteng Division over the issue of regionalism in 1956. Together they formed the Banteng Council and declared the Banteng Charter, demanding greater regional autonomy, especially in matters of defence and finance. The Banteng council was opposed by the local branch of the PKI, which prompted the

\footnotetext{
${ }^{76}$ A. Kahin, "Some Preliminary Observation on West Sumatra during the Revolution," Indonesia, 18 (1974): pp. 76-117.

${ }^{77}$ Kahin, Rebellion to Integration, p. 123.

78 The tension between Islam and the Republican government in West Sumatra also affected the relationship with communists in the region. During the March 1947 coup the Army commander was Colonel Ismael Lengah, who had a secular education and was considered by Islamic groups to be a socialist and a follower of Tan Malaka. Lengah refused to return weapons of the Islamic militia even though Muhammad Natsir and the Vice President Mohammad Hatta at that time asked him to do so. See, Ibid., pp. 125-7
} 
formation of a local network called the Joint Movement against Communism (Gerakan Bersama Anti Komunisme, GEBAK) on 4 September 1957. Led by Colonel Dahlan Djambek, GEBAK accused communist groups of accepting funds from foreign Chinese, also suggesting that communism had caused the split between Sukarno and Hatta. Among the propaganda used by GEBAK was the statement that West Sumatra was considered as Islamic and national government was communist. ${ }^{79}$ Mansoer Sani, the new military head of Sawah Lunto Sijunjung district removed all communists, mostly immigrants from Java, from civilian and military positions and arrested their leaders in 1957.

The PRRI movement in West Sumatra was headed by Syafruddin Prawiranegara and Muhammad Natsir. According to Leirissa, ${ }^{80}$ the rebellion was caused by four factors. First, there had been a significant Javanisation of the outer islands from 1955, which local powerbrokers feared would enable the national government to easily control Central Sumatra. Second, the national economy was in crisis, and poverty was rampant not only among civilians but among lower level military units in the region. Third, there had been a history of local and national coup attempts by communists, including the local attempt on 3 March 1947 in West Sumatra. Finally, fragmentation in the local and national armed military made a regional uprising possible. Kahin, ${ }^{81}$ however, suggests that the PRRI was made possible because of US support as part of attempts to encourage a national front against communism. The national government sent military forces to the province and PRRI leaders were captured and killed in 1961.82 Following the rebellion, control over the regional army was put in the hands of communist groups within the Diponegoro Division, who proceeded to entrench their power in the local military. ${ }^{83}$ Civilians who supported

\footnotetext{
${ }^{79}$ Kahin argues that Djambek's accusations should be contextualised in the fact that he had been forced to resign from the Indonesian military in Jakarta after being charged with corruption, and was seeking opportunities for influence on his return to Padang. See, Ibid., pp. 202-4.

80 R.Z. Leirissa, PRRI Permesta: Strategi Membangun Indonesia Tanpa Komunis (Jakarta: Pustaka Utama Grafitti, 1991).

${ }^{81}$ Kahin, Rebellion to Integration, p. 198, and p. 207.

82 Ibid., p. 226.

${ }^{83}$ Ibid., p. 236.
} 
the rebellion were also detained in jails or kept under house arrest. ${ }^{84}$ The political repression that followed the PRRI prompted many Minangkabau to migrate to other regions, including Jakarta, and also to Malaysia.

The involvement of Masyumi leaders in the PRRI and Darul Islam rebellions led Sukarno to ban the party and imprison a number of its leaders, including Syafruddin and Natsir. The same fate befell the Indonesian Socialist Party (Partai Sosialis Indonesia, PSI) and its leaders, including Sukarno's long-time nemesis, the West Sumatran Sutan Sjahrir. ${ }^{85}$ In West Sumatra, the banning of Masyumi meant that Muslims voters were forced to support the traditionalist Perti, which had rejected support for the Banteng Council and the PRRI movement and agreed with Sukarno's Guided Democracy. ${ }^{86}$ It was in this political context that Haji Abdul Malik bin Abdul Karim Amrullah, better known as Hamka, the son of the founder of Muhammadiyah's West Sumatra branch, Haji Rasul, began criticising Sukarno from Jakarta. Hamka had worked in the Ministry of Religion in Jakarta from 1951 to 1960, also serving as a Masyumi member of the Indonesian Constituent Assembly representing Central Java from 1955 to 1960. Hamka challenged Sukarno's personal and political behaviour, including his polygamous tendencies and his close association with communism, a view widely shared in West Sumatra. Sukarno responded by having Hamka arrested in 1964 under the Subversion Law.

After the failure of the alleged communist coup in Jakarta in 1965, the national government held trials for regional communist leaders in Padang, including Major Djohan Rivai, Leitenant Colonel Bainal and Sukirno as well as PKI members such Djajusman. ${ }^{87}$ Tens of thousands of communists were jailed without trial, and although no exact figures are available on the number of those killed, ${ }^{88}$ it is clear that the numbers were significant. In addition, communist officials who had been dominant in the administrative structure of West Sumatra after

\footnotetext{
${ }^{84}$ Ibid., p. 228.

85 Ibid., p. 236.

${ }^{86}$ Ibid., p. 246.

${ }^{87}$ Ibid., p. 240.

${ }^{88}$ Ibid., p. 248.
}

$112 \mid \begin{aligned} & \text { JOURNAL OF INDONESIAN ISLAM } \\ & \text { VOLUME O7, NUMBER O 1, JUNE 2013 }\end{aligned}$ 
the PRRI were replaced by anti-communist military officers in $1966 .{ }^{89}$ The regional army under Colonel Poniman also isolated traditional adat and religious associations that had been associated with communism, such as the Supreme Consultative Council of the Adat of the Minangkabau World (Majelis Tinggi Kerapatan Adat Alam Minangkabau, MTKAAM) and the Islamic Educational Movement Party (Partai Pergerakan Tarbiyah Islamiyah, Perti). ${ }^{90}$ In their place, a new adat organisation, the Minangkabau Adat Consultative Body (Lembaga Kerapatan Adat Alam Minangkabau, LKAAM) and a group called the Contact Body for the Struggle of the Islamic Community (Badan Kontak Perjuangan Umat Islam, BKPUI) were established in 1966.91

\section{Islam and Politics in Suharto's Indonesia}

In an attempt to mend bridges in West Sumatra, on coming to power, the Suharto regime appointed Harun Zain, a Minangkabau born in Jakarta but then a teacher at Andalas University in Padang, as governor of the province in 1967. Harun was eager to show West Sumatrans that they would benefit by working with the New Order, working hard to develop agricultural and communication infrastructure in the province. In 1969, as part of the lead-up to the 1971 election, the military officer Saafroedin Bahar was appointed head of the local Golkar branch. He subsequently led the campaign to convince West Sumatra's people that support for Golkar was crucial for the continuance of regional development (Interview with Saafroedin Bahar, 3 November 2010). In West Sumatra, Golkar ultimately bettered its national average, winning 63 per cent of the votes in that election.

Harun also sought to re-establish an understanding of Minangkabau heritage and regional identity that did not emphasise Islam, for example by promoting the use of traditional architecture in official buildings. As part of this push, Islamic leaders were sidelined in Harun's regional development program. Supporters of Masyumi, for

\footnotetext{
${ }^{89}$ Ibid., p. 235.

90 Ibid., pp. 245-6.

${ }^{91}$ Interview with Saafroedin Bahar, 3 November 2010.
} 
example, were asked to distance themselves from political Islam in the interests of regional development.

Azwar Anas, a military officer, replaced Harun Zain as Governor of West Sumatra in 1977. The greatest challenge he faced during his term in office was that of implementing Law No. 5/1979 on Village Governance, which determined the basis on which funding was to be allocated to each province. Although Azwar succeeded in establishing a way of identifying villages (based on the Javanese concept of the desa) that did not disadvantage the province in terms of funding (Kahin 1999: 258), the implementation of this law undermined the status of the nagari, which not only linked rural society to land, inheritance and rice cultivation but also to social and cultural relationships, including those based on kinship and cultural Islam.

In an attempt to retain some traditional authority, Azwar established a Village Adat Council (Kerapatan Adat Nagari, KAN) within each desa in 1983. ${ }^{22}$ However, local dissatisfaction with the division of nagari into several desa continued to grow. After Hasan Basri Durin was appointed governor in 1987, he overturned Azwar's policy, regrouping some of the smallest desa in $1988 .{ }^{93} \mathrm{He}$ also encouraged cooperation between traditional rural leaders, Islamic scholars, intellectuals and government officials, establishing the Manunggal Sakato program in 1990. In the following year he established Village Development Discussion Bodies (Musyawarah Pembangunan Nagari, MPN), which were made up of both nagari leaders and government officials.

Muchlis Ibrahim replaced Durin as governor in 1997 but he stepped down two years later when his recommendation for the position of Deputy Governor was rejected by the central government. Ibrahim had supported Nurmawan, a bureaucrat in the provincial office. However, Syarwan Hamid, the Minister for Internal Affairs, appointed Zainal Bakar, the candidate backed by the regional parliament (Dewan Perwakilan Rakyat Daerah, DPRD). The tension between the governor and the DPRD marked the beginning of a new era in West Sumatran local politics, in which Islam once more became

\footnotetext{
${ }^{2}$ Kahin, Rebellion to Integration, p. 260.

93 Between 1987 and 1996, the number of desa decreased by 1,000. See Ibid., p. 261.
} 
a pivotal factor after many years in the wilderness under the New Order.

\section{Conclusion}

The paper has demonstrated the relationship between Islam and Minangkabau culture was simultaneously accommodating and contested, and that the strong association between Islam and regional identity only solidified in the post-Suharto era. The Minangkabaus'connection with the Malay world increased the acceptance of orthodox Islam, first introduced by reformist Muslims coming back from Mecca in the 17th century. Gradually, orthodoxy, and later Wahabism, largely replaced the Sufi form first adopted, which was more accommodating of local beliefs. However, as also shown here, Islam as an ideology was subordinated after Independence days, and again under the New Order, this time to a largely secular formulation of national identity.

Indeed, it has only been in the post-Suharto period that Islam has assumed a hegemonic position in Minangkabau identity discourse. In contemporary West Sumatra, regional governments has been utilising claims that local customs are based on Islam and Islam is based on the Qur'an (Adat Basandi Syarak, Syarak Basandi Kitabullah, ABS-SBK). This assertion is ubiquitous, appearing as justification for almost every political decision made at the provincial level and below. Moreover, every disaster, from the 1997 Asian Financial Crisis to natural disasters such as floods, landslides and earthquakes, has been attributed to the community's failure to meet its religious obligations. For example, after the 2004 tsunami, large billboards were displayed throughout the city of Padang proclaiming 'religiosity must be practised in order to prevent a tsunami'. []

\section{References}

\section{Books and Articles}

Abdullah, Taufik. "Adat and Islam: An Examination of Conflict in Minangkabau." Indonesia 2, no. 1 (1966): pp. 1-24.

Schools and Politics: the Kaum Muda Movement in West Sumatra (1927-1933). Ithaca, N.Y: Cornell Modern Indonesia Project, Cornell University. 1971. 
- "Modernisation in the Minangkabau World: West Sumatra in the Early Decades of the Twentieth Century." in Holt C. (ed.), Culture and Politics in Indonesia.Ithaca: Cornell University Press, 1972.

---------. "Islam, History, and Social Change in Minangkabau." Thomas L.L. and Benda-Beckmann, F.V. (eds). Change and Continuity in Minangkabau: Local, regional and Historical Perspectives on West Sumatra. Athens, Ohio: Ohio University Centre for International Studies, 1985.

Al-Attas, S.M.N. Preliminary Statement on a General Theory of the Islamization of The Malay-Indonesian Archipelago. Kuala Lumpur: Dewan Bahasa dan Pustaka. 1969.

Andaya, L.Y. "Aceh's Contribution to Standards of Malayness." Archipel, 61, no. 1 (2001): pp. 29-68.

Azra, Azyumardi. Jaringan Global dan Lokal: Islam Nusantara. Bandung: Mizan. 2002.

-. The Origins of Islamic Reformism in Southeast Asia : Networks of Malay-Indonesian and Middle Eastern Ulama in the Seventeenth and Eighteenth Century. Honolulu: University of Hawaii Press, 2004.

Benda, H.J. The Crescent and the Rising Sun: Indonesian Islam under the Japanese Occupation. The Hague: W. van Hoeve. 1958.

Biezeveld, R. 'The Many Roles of Adat in West Sumatra.' in J.S. Davidsonand D. Henley (eds). The Revival of Tradition in Indonesian Politics: the Deployment of Adat from Colonialism to Indigenism. London, New York: Routledge. 2007.

Blackwood, E. "Representing Women: The Politics of Adat Minangkabau Writing." The Journal of Asian Studies, 60, no. 1 (2001): pp. 125-149.

Colombijn, F. Paco-paco (kota) Padang: Sejarah Sebuab Kota di Indonesia pada abad ke 20 dan Penggunaan Ruang Kota. Yogyakarta: Penerbit Ombak, 2006.

Dobbin, C. Islamic Revivalism in a Changing Peasant Economy: Central Sumatra, 1784-184. London: Curzon Press, 1983.

Drakard, J. A. Malay Frontier: Unity and Duality in A Sumatran Kingdom. New York: Southeast Asia Program Cornell University, 1990. 
Federspiel, H.M. Persatuan Islam, Islamic Reform in Twentieth Century Indonesia. New York: Ithaca Cornell University, 1970.

--------. Localising Power in Post-authoritarian Indonesia: A Southeast Asia Perspective. Stanford: Stanford University Press, 2010.

Hadler, J. "A Historiography of Violence and the Secular State in Indonesia: Tuanku Imam Bondjol and the Uses of History." The Journal of Asian Studies, 67, no. 3 (2008a): pp. 971-1010.

--------. Muslims and Matriarchs. London: Cornell University Press, 2008b.

Howell, J.D. "Sufism and the Indonesian Islamic Revival." The Journal of Asian Studies, 60 no. 3 (2001): 701-729.

Jaspan, M.A. "In Quest of New Law: The Perplexity of Legal Syncretism in Indonesia." Comparative Studies in Society and History, 7, no. 3 (1965): pp. 252-266.

Johns, H. "Sufism as A Category in Indonesian Literature and History." Journal of Southeast Asian History, 2, no. 2 (1961): pp. 1023.

Kahane, R. "Religious Diffusion and Modernisation: A Preliminary Reflection on The Spread of Islam In Indonesia and Its Impact on Social Change.” European Journal of Sociology, 21, no. 1 (1980): pp. 116-137.

Kahin, A. "Some Preliminary Observation on West Sumatra during the Revolution.” Indonesia, 18 (1974): pp. 76-117.

- Rebellion to Integration: West Sumatra and the Indonesian Polity. Amsterdam: Amsterdam University Press, 1999.

Laffan, M. Islamic Nationhood and Colonial Indonesia: The Umma Below the Winds. London and New York: RoutledgeCurzon, 2003.

Leirissa, R.Z. PRRI Permesta: Strategi Membangun Indonesia Tanpa Komunis. Jakarta: Pustaka Utama Grafitti, 1991.

Manan, I. "A Short History of Minangkabau." in A. Summerfieldand J. Summerfield. Walk in Splendor: Ceremonial Dress and the Minangkabau. Los Angeles: UCLA Fowler Museum of Cultural History, 1999.

Milner, A.C. "Islam and Malay Kingship." Journal of Royal Asiatic Society, 113 (1981): pp. 46-70. 
Noer, Deliar. The Modernist Muslim Movement in Indonesia 1900-1942. Kuala Lumpur: Oxford University Press, 1973.

Oki, A. Social Change in the West Sumatran Village: 1908-1945. 1978. Available at: http://hdl.handle.net/10086/16895, accessed on 12 February 2010.

Reid, A. "Understanding Melayu (Malay) as a Source of Diverse Modern Identities." Journal of Southeast Asian Studies, 32 (2001): pp. 295-313.

-------. An Indonesian Frontier: Acehnese and Other Histories of Sumatra. Singapore: Singapore University Press, 2005.

Roff. W. The Origins of Malay Nationalism. New Haven: Yale University Press, 1964.

Trimingham, J.S. The Sufi Orders in Islam. Oxford: Oxford University Press, 1998.

Utrecht, E. "The Muslim Merchant Class in the Indonesian Social and Political Struggles." Social Compass, 31, no. 1 (1984): pp. 27-55.

van Dijck, C "Islam and Socio-Political Conflicts in Indonesian History." Social Compass, 31, no. 1 (1984): pp. 5-25

Vickers, A. A History of Modern Indonesia. Cambridge: Cambridge University Press, 2005

Voll, J. "Foreword." in J.S. Trimingham (ed.). The Sufi Orders in Islam Oxford: Oxford University Press, 1998.

Woodward, M. Islam in Java: Normative Piety and Mysticism in the Sultanate of Yogyakarta. Tucson: University of Arizona Press, 1989. 